\title{
The Application of e-Court as an Effort to Modernize the Justice Administration in Indonesia: Challenges \& Problems
}

\author{
Sahira Jati Pratiwi ${ }^{1}$, Steven$^{2 *}$, Adinda Destaloka Putri \\ Permatasari $^{3}$
}

${ }^{1}$ Faculty of Social and Political Sciences, Universitas Jenderal

Soedirman, Purwokerto, Indonesia

${ }^{2,3}$ Faculty of Law, Universitas Negeri Semarang, Indonesia

Corresponding Author: Steven, email: stevenchen@students.unnes.ac.id

\begin{abstract}
The Industrial Revolution 4.0 was an era marked by the carrying out of various technology-based human activities as a result of the transformation of life. This revolution has penetrated into various sectors of life, including the rule of justice. In order to face this revolution, the court is demanded to be able to provide legal services electronically through an application called e-Court. This application is an embodiment of The Electronic Justice System which has become a commitment of the Supreme Court of the Republic of Indonesia with the aim to synergize the role of information technology and procedural law. The presence of e-Court is expected to be able to overcome various problems in the Indonesian judicial process, such as the resolution of disputes that are running slowly, less responsive courts, and expensive judicial costs. Juridically, Law Number 48 of 2009 contains judicial principles. As stated in the law, cases submitted to the court must be resolved quickly, simply, and at a low cost. This means that the whole judicial process must be carried out with regard to effectiveness and efficiency in order to overcome obstacles in the justice administration. Thus, the presence of e-Court is expected to overcome various problems in the administration of justice with technology-based services. These services include online case registration, online case fee down payment, online party summons, and electronic trials. Therefore, this paper intends to describe the problems and challenges e-Court application in an effort to face the industrial revolution 4.0 in Indonesia.
\end{abstract}

Keywords: Industrial Revolution 4.0; e-Court Implementation; Justice Administration

\section{How to cite:}

Pratiwi, S. J., Steven, S., \& Permatasari, A. D. P. (2020). The Application of e-Court as an Effort to Modernize the Justice Administration in Indonesia: Challenges \& Problems. Indonesian Journal of Advocacy and Legal Services, 2(1), 39-56. https://doi.org/10.15294/ijals.v2i1.37718 


\section{A. Introduction}

Current era of globalization and rapid technological development is affecting the overall economies and creating new challenges along with openings for the countries to grow and develop. With all the segments, Courts are also part of this race to meet the challenges and adopt new technologies devoid for eCourt Implementation, additionally providing effective and efficient judicial services to the clients. ${ }^{1}$ The Industrial Revolution 4.0 triggered rapid change. This revolution introduces modern technologies which support the connectivity of the entire components within the industries. ${ }^{2}$ Therefore, justice institutions in each country must have legal intelligence to respond to the revolution. Law enforcement officials are required to be professional in completing heavy tasks in the field of law in the future. When viewed in the constellation of the modern legal system, the existence of a judicial institution includes the task of resolving disputes to suppress the rule of law. The existence of a judicial institution is intended as a facility to uphold the authority of the law by providing access to justice for the parties to the dispute. In practice, the operation of the law to realize its function as a means of resolving disputes is not as simple as written. On one hand, sometimes the law can reduce obstacles and be able to carry out their duties, but on the other hand the law can fail to distribute the justice. ${ }^{3}$

The failure of the law to distribute justice to the community can be caused by an unresponsive justice administration. Research carried out by the Judicial Independence Study and Advocacy Institute notes that there are three main problems inherent in the administration of justice in Indonesia. ${ }^{4}$ First, the handling of cases that run slowly. In the Supreme Court, the handling of cases must pass about 26 (twentysix) stages from the time the general bureau receives the case file until it is sent back to the claiming court. Based on the Supreme Court Decree No. 214 concerning the period of handling cases, at the cassation level the maximum period of handling cases is 250 (two hundred and fifty) days.

1 Monika Singh., Sahu, G. P., Dwivedi, Y., Rana, N. P., \& Tamilmani, K, Success Factors for e-Court Implementation at Allahabad High-Court, In PACIS, 2018, p. 137. URL: https://aisel.aisnet.org/pacis2018/137

2 Akhmad Hidayatno., Destyanto, A. R., \& Hulu, C. A, Industry 4.0 technology implementation impact to industrial sustainable energy in Indonesia: A model conceptualization, Energy $\quad$ Procedia, Vol. 156, 2019, pp. 227-233. https://doi.org/10.1016/j.egypro.2018.11.133

3 Ali Achmad, 2004, Sosiologi Hukum Kajian Empiris terhadap Pengadilan. Jakarta, STIH IBLAM Publishing, p. 60

4 Indra Rahmatullah, Menerobos Sekat Administrasi Peradilan, Refleksi Hukum: Jurnal Ilmu Hukum, Vol. 1 No. 2, 2017, pp. 117-130. https://doi.org/10.24246/jrh.2017.v1.i2.p117-130 
The length of case handling by the court is certainly contrary to the principle of justice which is simple, fast and low cost. If a case is left too protracted and not finished, it will damage the sense of justice itself. Second, the spread of administrative responsibility for handling cases. The long flow passes through 3 (three) different work units, namely the General Bureau, the Directorate of Institutions and Procedures, and the Registrar's Office. This condition complicates accountability for administration and settlement of a case. So, this will have an impact on the supervision of cases that are not running effectively. Third, the recording of case handling processes is not yet entirely based on information technology. Settlement of cases that are recorded manually with the case register starts from one stage to the next, causing a delay in the case handling process. The recording of judicial administration using information technology has become important in facing the industrial revolution 4.0.

In addition, the Ombudsman Report of the Republic of Indonesia said that in the past three years, from 2014-2016, the District Court was the judicial institution that was the most widely complained of 394 complaints with the type of administrative mall most publicly complained of by the postponement of protracted cases of 215 complaints, 117 complaints about incompetence in the performance of the justice system, and 115 complaints about deviations from the procedure. When compared to 2017 before the use of e-court, the number of cases received (registered) increased by $10.65 \%$, the number of case expenses increased by $3.82 \%$, the number of cases decided increased by $7.07 \%$, while the number of remaining cases decreased by 34.73 $\%$. While the rest of the 2018 case is also the smallest number in the history of the Supreme Court. Referring to the remaining cases in 2012 which amounted to 10,112 cases, until 2018 the Supreme Court was able to erode the remaining cases of 9,206 cases or $91.04 \%$. The comparison shows the ratio of productivity to decide the Supreme Court in 2018 rose to $95.11 \%$ or an increase of $2.89 \%$ compared to the ratio of productivity to decide in 2017 of $92.23 \%$. If compared with the target set at $70 \%$, the achievement exceeded the target of $25.11 \%{ }^{5}$

In this modern era, life based on electronics or in other words instant or practical is a necessity for the community and is now even a basic necessity. In addition, along with the development of technology that resulted in the world such as not having a barrier can bring positive changes to the

$5 \quad$ https://ptun-yogyakarta.go.id/index.php/artikel/193-e-court-dan-masa-depan-sistemperadilan-modern-di-indonesia.html. [Accessed February 22, 2020]. 
examination mechanism at the trial. ${ }^{6}$ One example is the application of eCourt to overcome various problems that hamper the administration of justice. In 2018, the Government of Indonesia launched a new court service system that replaced the old method or manually in order to facilitate the public, especially in terms of administrative and cost management. The program called e-Court began to be launched by the Indonesian government. e-Court itself is a service for registered users to register cases online, get an estimated online court fee, online payments and calls made by electronic channels. In this case the community does not need to bother to register the lawsuit directly to any court. Only by accessing e-Court can people report online to any court of law online.

The application of e-Court is regulated in Republic of Indonesia Supreme Court Regulation No. 3 of 2018 concerning electronic case administration in courts. This regulation is the first legal basis recently issued in Indonesia which further regulates the use of e-Court in court services in Indonesia in addition to the procedure for court services manually as a material source. Law enforcement, legal aid, legal services and advocacy in the industrial revolution 4.0 era have their own characteristics of challenges. ${ }^{7}$ From the description, this paper is trying to answer some problems. First, what is the legal basis for implementing electronic court in Indonesia? Second, what features are contained in the electronic court and how are the challenges and problems in using electronic court in Indonesia?

\section{B. Method}

This paper uses a normative juridical approach that tries to analyze and identify the application of e-Court in an effort to deal with the industrial revolution 4.0 in Indonesia. The approach is intended to study the principles and legal theories related to this problem. In addition, this paper also analyzes the relationship between one statutory regulation and another. Therefore, the data used in this paper are secondary data, that is data obtained from books and data published by law enforcement institutions.

6 Ni Putu Riyani Kartika Sari, Eksistensi E-Court untuk Mewujudkan Asas Sederhana, Cepat, dan Biaya Ringan dalam Sistem Peradilan Perdata di Indonesia, Jurnal Yustitia, Vol. 13 No. 1, 2019, pp. 80-100. URL: http://www.ojs.unr.ac.id/index.php/yustitia/article/view/275

7 Ridwan Arifin, Legal Services and Advocacy in the Industrial Revolution 4.0: Challenges and Problems in Indonesia, Indonesian Journal of Advocacy and Legal Services, Vol. 1 No. 2, 2000, pp. 159-162. https://doi.org/10.15294/ijals.v1i2.36488 


\section{Result and Discussion}

\section{The Legal Basis of e-Court Application}

The Chairman of the Supreme Court of the Republic of Indonesia officially launched the e-Court application on Friday, July 13, 2018 at the Novotel Hotel, Balikpapan. The e-Court application is an implementation of Supreme Court Regulation Number 3 of 2018 concerning Case Administration in the Judiciary. There are several features found in this application. Through the e-Court application, cases can be registered electronically (e-filling), payment of case down payments electronically (epayment), summons and notices to parties who litigate electronically (esummons). There are 910 courts throughout Indonesia that are connected to the e-Court system. All three features in the e-Court application have been integrated with the Case Search System, Case Information System, and Decision Directory. ${ }^{8}$ Before the promulgation of Supreme Court Regulation Number 3 of 2018 concerning Case Administration in Electronic Courts, the Supreme Court had made rules relating to the use of Information Technology, including: 9

1) Decision of the Chief Justice of the Supreme Court Number 1-144 / KMA / SK / 1/2011 concerning Guidelines for Information Services in the Court

2) Guidelines for Draft and the Principles of Accessibility of Court Websites within the Supreme Court

3) Indonesian Supreme Court Circular Letter Number 14 of 2010 concerning Electronic Documents as Completion of Appeal for Cassation and Review as amended by the Indonesian Supreme Court Circular Letter Number 1 of 2014 concerning Amendments to the Supreme Court Circular Letter Number 14 of 2010 concerning Electronic Documents as Completion of an Application for Cassation and Reconsideration

4) Circular of the Director General of the General Judicial Agency Number 3/Ju/Hm.02.3/6/2014 concerning Administration of Information Technology-Based Courts in the General Judicial Jurisdcition

5) Republic of Indonesia Supreme Court Regulation No. 9 of 2016 concerning Guidelines for Handling Complaints (Whistleblowing System) in the Supreme Court and Judiciary Bodies Under It, in this regulation there

$8 \quad$ Ifa Atur Kurniati. (2019, March). Mengembalikan Citra Peradilan melalui E-Court. In Conference on Communication and News Media Studies (Vol. 1), 176-185. URL: http://proceeding.umn.ac.id/index.php/COMNEWS/article/view/1093

$9 \quad$ Hary Djatmiko, Implementasi Peradilan Elektronik (e-Court) Pasca Diundangkannya PERMA Nomor 3 Tahun 2018 Tentang Administrasi Perkara di Pengadilan secara Elektronik, Legalita, Vol. 1 No. 1, 2019, pp. 22-32. 
are arrangements regarding the application of the Supervision Information System

6) Decree of the Director General of the Religious Courts of the Supreme Court of the Republic of Indonesia Number 2273.A / Kp.01.1 / SK / VII / 2014 concerning Technical Guidelines for the Implementation and Utilization of the Tabayun Portal within the Religious Courts of the Supreme Court of the Republic of Indonesia

7) Circular of the Director General of the Military Courts and State Administrative Courts Number 1532 / Djmt / B / 12/2012 dated 11 December 2012.

In Article 2 of the Republic of Indonesia Supreme Court Regulation No. 3 of 2018, it is stated that this regulation is intended as a legal basis for the administration of case administration in an electronic court to support the realization of orderly professional administration, transparent, accountable, effective, efficient and modern. Article 3 of the Republic of Indonesia Supreme Court Regulation No. 3 of 2018 states that electronic case administration arrangements in this regulation apply to types of civil, religious, military and state administrative matters. In the preamble section of the Supreme Court Regulation, it was stated that the regulation was formed in order to create a simple, fast and low-cost trial in order to overcome obstacles in the process of administering justice. Furthermore, it was also mentioned that the regulation was intended to keep abreast of the times which required the case administration services in court effectively and efficiently. The court in upholding and applying the law in handling cases that come to him is expected to be able to work optimally to create an effective and efficient trial as mandated in article 2 paragraph (4) of Law No. 48 of 2009 concerning Judicial Power which says "The judiciary is carried out simply, quickly and at low cost" and in article 4 paragraph (2) it also says that "the court helps justice seekers and tries to overcome all obstacles and obstacles in order to be able to achieve all obstacles to achieve them. justice that is simple, fast and low cost "and can provide a sense of justice according to the law without discriminating against people, but many people assume that what is expected in the provisions of the article above is still far from realized. ${ }^{10}$

The validity of cases registered through the E-Court normatively can be justified because it already has a legal basis with the Supreme Court

Muhamad Iqbal, Susanto, \& Sutoro, M, Efektifitas Sistem Administrasi E-Court dalam Upaya Mendukung Proses Administrasi Cepat, Sederhana dan Biaya Ringan di Pengadilan, Jurnal Ilmu Hukum, Vol. 8 No. 2, pp. 302-315. http://dx.doi.org/10.30652/jih.v8i2.7286; Ridwan Arifin, Legal Reform Discourse in Indonesia and Global Context: How Does The Law Respond to Crime. Journal of Law and Legal Reform, Vol. 1 No. 2, 2020, pp. 193-196. 
Regulation No. 3 of 2018 concerning Guidelines for Case Administration in the Electronic Court, although in practice it still experiences several obstacles as the author has pointed out, E- Court is a demand for changing times and as one form of modern justice. Supreme Court Regulation No. 3 of 2018 regulates new matters, namely: Electronic case registration, electronic court summons and electronic copy of decision / determination. ${ }^{11}$ Thus, the application of technology is not only beneficial to society but also to government for a better performance that is cleaner, more accurate, and accountable. ${ }^{12}$

\section{Electronic Court Application}

The case e-court application is expected to improve services in its function of accepting online case registrations while the public will save time and money when registering a case. The e-court application spaces are as follows: 13

\section{a. Online Case Registration}

Online case registration in the e-court application for this time just opened the type of registration for the lawsuit and will continue to grow. Lawsuit registration in court is a type of case registered in general court, religious court and state administration court which in its registration requires more effort or effort, and this is the reason for making e-court, one of which is ease of doing business. The benefits of online case registration through the e-court application that can be obtained from this application are:

1) Save time and money in the case registration process.

2) Payment of down payment costs that can be made in a channel

3) Documents are well archived and can be accessed from various locations and media.

4) Faster data retrieval process.

b. Electronic Payment

In conventional case registration, the prospective plaintiff / applicant faces the cashier by submitting a lawsuit / petition along with a power of

11 Raden Raffi Septiar \& Sholahuddin Harahap, Implementasi Pengadilan Elektronik (ECourt) Pada Badan Peradilan di Indonesia dihubungkan dengan Asas Sederhana Cepat dan Biaya Ringan, Prosiding Ilmu Hukum, Vol. 5 No. 2, 2019, pp. 902-907. URL: http://hdl.handle.net/123456789/20728

12 Kukuh Santiadi, Expanding Access to Justice Through E-Court in Indonesia, Prophetic Law Review, Vol. 1 No. 1, 2019, pp. 75-89. https://doi.org/10.20885/PLR.vol1.iss1.art5

13 Ika Atikah, Implementasi E-Court dan Dampaknya Terhadap Advokat Dalam Proses Penyelesaian Perkara di Indonesia,2018, pp. 107-127. URL: http://osc.fhisip.ut.ac.id/; Diniyanto, A. (2020). Bureaucracy in Perspective of Government Administration Laws. Law Research Review Quarterly, 6(1), 85-90; Puhi, O., Akili, R. H., \& Moonti, R. M. (2020). The Settlement of Abuse of Authority by Government Officials. The Indonesian Journal of International Clinical Legal Education, 2(1), 85-100. 
attorney to pay (SKUM). Prospective plaintiff / applicant pays in advance the case fees in accordance with those stated in the SKUM. Then, the cashier does the following things:

1) Receive the money and record it in the court fee journal.

2) Sign and give the case number and the full sign on the SKUM.

3) Return the claim / request letter and SKUM to the prospective plaintiff / applicant.

4) Submit the deposit in advance to the treasurer of the case.

In the online fee payment system (e-SKUM), registered users will immediately get a SKUM (Power of Attorney to Pay) generated electronically by the e-court application. In the process of generating it will already be calculated based on what components of the cost are determined and configured by the court, and the amount of the cost of the radius which is also determined by the head of the court so that the calculation of estimated costs has been calculated in such a way and produces an electronic SKUM or eSKUM. The e-SKUM application is the result of an innovation carried out by the Pekanbaru district court. e-SUKM itself is an electronic application to calculate the court fee for justice seekers in a district court. After ascertaining how much the court fee has to be paid, then can immediately register and can directly pay the case fee through several media, including through the EDC (Electronic Data Capture) machine at the information desk, ATM (Automatic Teller Machine) and cash deposits at partner banks. with the court. This application is a web-based application, an application that is installed on a server and is accessed using a web browser or known as a browser through an internet network, so that the parties know from the beginning how much a case down payment must be paid so as to create efficiency and transparency in costs case. In addition to being able to make it easier for the public to register and pay for civil lawsuits, this innovation can also help civil officials in court in providing services.

\section{c. Trial Documents}

The e-court application also supports sending court documents such as replicas, duplicates, conclusions and or electronic answers that can be accessed by the court and the parties.

\section{d. Electronic Summons}

In accordance with Supreme Court Regulation Number 3 of 2018, calls made for registration are carried out using e-court, then summons to registered users are carried out electronically by moving to the electronic domicile address of the registrant user. However, for the defendant the first summons is to be done manually and when the defendant is present at the first trial, approval will be approved electronically or not, if agreed, the 
defendant will be electronically related to the electronic domicile provided and not supported. done manually as usual.

According to the Supreme Court Regulation Number 3 of 2018, Article 12 (1) Summon delivered electronically to:

1) Plaintiff / applicant who registers electronically and gives written approval;

2) Defendant / respondent or other party who has stated his written consent to be called electronically; and

3) Legal counsel must obtain written approval from the principal to proceed electronically.

Based on the description above, it can be said that electronic summons is not necessarily because they require written approval from litigants. If one party does not agree to be called electronically, the call will be made manually.

There are various types of electronic applications. Saman \& Heider identified number of electronic court applications and services being implemented in a few countries, summerises as follows: ${ }^{14}$

1) United States

a. Public Access to Court Electronic Records

b. PACER Case Locator

c. PACER Fee Waiver

2) Australia

a. eSearch - for public to search cases

b. eFiling - electronic document lodgment

c. eCourtroom - virtual courtroom for pre-trial matters

d. eCase Administration - for legal practitioners and parties to communicate with court chamber staff securely

e. Commonwealth Courts Portal

3) Singapore

a. eAlternative Dispute Resolution

b. eJustice Judges' Corridor

c. Justice Online (JOL)- a global forum and virtual think-tank for judges

d. Electronic Filing System (EFS)

e. Small Claims Tribunals - Electronic Filing System (SCT-EFS)-forum for the resolution of small claims

f. Automated Traffic Offence Management System (ATOMS): an eService which allows the public to enquire on their Traffic Police, Urban

14 W. S. W. M Saman \& Haider, A, Electronic court records management: a case study (Doctoral dissertation, IBIMA-International Busines Information Management Association), 2012, pp. 1-11. DOI: 10.5171/2012.925115 
Redevelopment Authority, Land Transport Authority and Housing Development Board court fines, plead guilty to the offences and make payment electronically

4) Canada

a. E-Filing- available in English and French that allows a party or the party's legal representative to file documents electronically with the Federal Court via a secure, Internetbased system, in all areas of the Court's jurisdiction.

b. Electronic Legal Service- Electronic legal service allows a party or the party's legal representative to serve documents electronically pursuant to Rule 147 of the Federal Courts Rules

5) United Kingdom

a. Money Claim Online for small claim

b. Payment of fine online

c. Possession Claim Online (PCOL): aims at managing property ownership claims online when tenants fail to pay rent

d. XHIBIT: provide information case hearing

6) India

a. E-Filling

b. Online dispute resolution mechanism (ODRM)

\section{Challenges and Problems}

The development of information technology in the industrial revolution 4.0 shows that the law seems to move slowly and it can be said that the law has difficulty to keep up with these developments. ${ }^{15}$ Meanwhile, as mandated in the constitution, Indonesia is a country based on law. As a consequence, law plays an important role for the survival of the nation and state. Technological advances in the Industrial Revolution 4.0 era have changed the way people in the digital age interact with one another. This fact not only forces regulators to change their approach, legal professionals and law enforcement officials must adapt. There are 3 reasons why legal professionals and law enforcement officials must be able to adapt, namely the presence of artificial intelligence, the commodification of law, and the increasingly easy communication. Artificial intelligence is basically a program design that allows computers to do a task or take decisions by imitating a way of thinking and human reasoning. Artificial intelligence or intelligence that is added to a

15 Edison H Manurun \& Heliany, I, Peran Hukum dan Tantangan Penegak Hukum Dalam Menghadapi Era Revolusi Industri 4.0, SOL JUSTISIO, Vol. 1 No. 2, 2019, pp. 128-135. URL: http://ojs.mputantular.ac.id/index.php/sj/article/view/354 
system that can be arranged in a scientific context. ${ }^{16}$ In the context of the application of electronic courts in Indonesia, law enforcement officials and justice seekers must be able to adapt to the new system. The following are the challenges and problems in implementing the electronic court.

\section{a. Advocates and Legal Professionals}

The electronic application of case administration in the court or the socalled e-Court has had a direct impact on the practice of advocates in Indonesia. The convenience provided in the advanced technology system ecourt service system becomes a necessity in the process of resolving cases in court with high mobility of the parties and legal advisers (advocates). Advocates are required to have an official account by registering in the e-court system so that their existence is recognized formally. However, advocates who do not have an e-court account will be hindered when defending clients in a number of courts, this is in accordance with Article 6 Paragraph 2 of the Supreme Court Regulation No. 3 of 2018 concerning Case Administration in Electronic Courts which reads: The Supreme Court has the right to reject registered user registration which cannot be verified. In addition, the e-Court system was also outlined in the Decree of the Chairperson of the Supreme Court of the Republic of Indonesia No.122 / KMA / SK / VII / 2018 of 2018 concerning Guidelines for Governance of Registered Users of the Court Information System and Decree of the Director General of the Indonesian Supreme Court of the Supreme Court No. .271 / DJU / SK / PS01 / 4/2018 concerning Implementation Guidelines for Supreme Court Regulation No. 3 of 2018 concerning Case Administration in the Electronic Court. ${ }^{17}$

Then, Supreme Court Regulation Number 3 of 2018 concerning Case Administration in Electronic Courts which was promulgated on April 4, 2018 covers the administration of civil, religious civil, military administrative and state business matters. Proof of membership in an advocate organization and proof of official oath by the high court are key requirements for registration in the e-Court. To meet the complex and changing needs of the community over time, it is clear that an advocate must keep abreast of developments. Because it is involved in a continuous learning process (continuous legal

16 Basri Basri, \& Hendrawati, H, Pendidikan Hukum Indonesia Berorientasi Pada NilaiNilai Pancasila dalam Era Revolusi Industri 4.0, Pelita Bangsa Pelestari $\begin{array}{llllll}\text { Pancasila, Vol. } & 14 & \text { No. } & 1\end{array}$ 2019, pp. 49-64. URL: https://pbpp.ejournal.unri.ac.id/index.php/JPB/article/view/7790

17 Atikah, Op.Cit., 122; Setyowati, H., \& Muchiningtias, N. (2018). Peran Advokat Dalam Memberikan Bantuan Hukum Kepada Masyarakat Dalam Perspektif Hak Asasi Manusia. Lex Scientia Law Review, 2(2), 155-168; Aji, W. (2019). The Implementation of Diversion and Restorative Justice in the Juvenile Criminal Justice System in Indonesia. JILS (Journal of Indonesian Legal Studies), 4(01), 73-88. 
education) and the obligation to learn is a life-long sentence for an advocate. In carrying out his profession, an advocate must be independent. He must be free from all fear, threats, and intervention from all parties in defending, giving legal advice, and representing the interests of his clients. In giving legal opinion he must be free from all forms of pressure and sometimes must be free to speak in public and in court (tribunal) for the benefit of clients and the community. In fact, he must also participate in the process of law reform.

Technological sophistication requires advocates and legal professionals to master the information technollogy, especially in the field of litigation in courts which are now in the e-Court system. Information technology (IT) is one of the most important drivers of innovation. ${ }^{18}$ It cannot be denied, the eCourt system has not been categorized perfectly in its implementation, so that advocates who have been registered in the membership data of advocate organizations who are annually sworn by oath advocates in the high court and receive a copy of the minutes of oath by being given a number issued by the high court must do data collection again by registering again in the eCourt system.

\section{b. The Justice Seekres}

A simple, fast and low-cost judicial process system is a new breakthrough in the justice system in Indonesia. This is in line with the notion of human rights which emphasizes the basic rights of human beings to one another and to society as a whole in the life of society, nation and state. In fact, justice seekers nowadays always end up in disputes or complicated legal processes that become social conflicts that cannot be resolved. Although the right to claim is a human right, it does not mean that the claim can be carried out without a predetermined legal basis. All rights claims filed by justice seekers must be based on existing procedural law. ${ }^{19}$ The guarantees and legal protection as well as legal assistance are regulated in the Universal Declaration of Human Rights in 1948 which recognizes the right of everyone to be admitted before the law wherever he is and guarantee that everyone is equal before the law and has the right to the same legal protection without discrimination. ${ }^{20}$

18 Michael Waidner \& Kasper, M. (2016, March). Security in industrie 4.0-challenges and solutions for the fourth industrial revolution. In 2016 Design, Automation \& Test in Europe Conference \& Exhibition (DATE) (pp. 1303-1308). IEEE. URL: https://ieeexplore.ieee.org/abstract/document/7459511

19 Susana Andi Meyrina, Perlindungan Hak Asasi Manusia bagi Masyarakat Miskin atas Penerapan Asas Peradilan Sederhana Cepat dan Biaya Ringan, Jurnal HAM, Vol. 8 No. 1, 2017, pp. 25-38. http://dx.doi.org/10.30641/ham.2017.8.25-38 Mampu di Indonesia, DIVERSI: Jurnal Hukum, Vol. 4 No. 2, 2019, pp. 218-236. 
The involvement of the Indonesian people both directly and indirectly contributes to law enforcement efforts, especially when viewed in terms of advances in information technology. Indonesia is ranked third in Asia for the largest number of Internet users. Even though many Indonesians use the Internet, not all Indonesians are technology literate. Geographical and economic factors are the cause. Indonesia's vast territory from Sabang to Merauke has caused the distribution of education, economy and even technology to be uneven in each region. In big cities like Jakarta, Surabaya or Bali, we easily can find the people who are holding sophisticated gadgets. Whether it's for business, entertainment, or mere prestige. But it is different with the interior of West Kalimantan or villages in East Nusa Tenggara far from the city center. Let alone understand how to use the Internet, computers or even television they may not have. In the advancement of information technology there is one tool that can be used to access information globally and that is indeed being symptomatic in Indonesian society, namely the Internet. ${ }^{21}$

The backwardness of Indonesian people in the use of information technology has become a major obstacle to the application of e-Court. In fact, there are still many justice seekers who have filed their claims conventionally. Of the 18 State Administrative High Courts that are ready to carry out electronic trials, only 4 courts have received electronic claims, while the other 16 courts have not received electronic claims. There are several obstacles that cause justice seekers to still choose to file lawsuits conventionally, ranging from the lack of electronic socialization of justice to the public, the new event law that is still unfamiliar to the public, to the readiness of the judicial apparatus for handling cases electronically. Another obstacle related to electronic justice is the absence of electronic justice in the examination of cases at the Appellate and Cassation level, so that justice seekers when going to appeal or appeal and still need to go to the State Administrative High Court for now still have to come to the State Administrative High Court for register legal remedies, hand over memory or counter memory, to take a copy of the decision. ${ }^{22}$ This shows that the majority

https://doi.org/10.32503/diversi.v4i2.374; Ridwan Arifi, Legal Protection and Law Enforcement: The Unfinished Works. Indonesian Journal of Advocacy and Legal Services, 2(1), 2020, pp. 1-4.

21 Rhodin Rodin, Transisi Masyarakat Indonesia Menuju Masyarakat Informasi, Jurnal Palimpsest, Vol. 4 No.2, 2013, pp. 2013-05. URL: http://journal.unair.ac.id/downloadfullpapers-palim9b3452ac9bfull.pdf

22 Sudarsono, Konsep Peradilan secara Elektronik di Lingkungan Peradilan Tata Usaha Negara Pasca Diundangkannya Peraturan Mahkamah Agung Nomor 3 Tahun 2018, Tanjungpura Law Journal, Vol. 3 No. 1, 2019, pp. 42-65. http://dx.doi.org/10.26418/tlj.v3i1.34495 
of Indonesian people still find it difficult to use information technology as an effort to seek justice. Therefore, deeper socialization is needed related to the use of e-Court in the community.

\section{Conclusion}

Electronic Court is a court instrument as a form of service to the community in terms of online case registration, online payment, sending trial documents (replicas, duplicates, conclusions, answers) and online summons. E-Court is also an answer to the complaints of justice seekers and law enforcement officials because the court proceedings are faster, more transparent and will significantly reduce judicial costs. The implementation of e-Court is regulated in Supreme Court Regulation Number 3 of 2018 concerning Electronic Case Administration in Courts. This renewal is expected to result in the implementation of law enforcement which gives satisfaction to justice seekers. This application has a positive impact on justice in Indonesia. With this application, meetings between litigants and court employees are limited so as to minimize the bribery crime that has been rife in the courts. In addition, the application of e-Court can also minimize deficiencies in the judicial process in Indonesia such as acts of harassment of the court (Contempt of court). the application of electronic court is a good step to modernize the administration of justice in Indonesia. However, there are still many challenges and problems that must be faced. The government and law enforcement officials must take appropriate steps to provide understanding to the public and legal professionals regarding the use of e-Court.

\section{E. Acknowledgments}

Authors would like to express the thakfullness to Faculty of Law, Universitas Negeri Semarang, as well as to Social and Political Science Faculty, Universitas Jenderal Soedirman. We would like to Mr Ridwan Arifin SH LLM for invaluable comment and discussion establishing this paper.

\section{F. Declaration of Conflicting Interests}

The authors state that there is no potential conflict of interest in the research, authorship, and/or publication of this article. 


\section{G. Funding}

None.

\section{H. References}

Aji, W. (2019). The Implementation of Diversion and Restorative Justice in the Juvenile Criminal Justice System in Indonesia. JILS (Journal of Indonesian Legal Ttudies), 4(01), 73-88. https://doi.org/10.15294/jils.v4i01.23339

Ali Achmad, 2004, Sosiologi Hukum Kajian Empiris terhadap Pengadilan. Jakarta, STIH IBLAM Publishing.

Angga, A., \& Arifin, R. (2019). Penerapan Bantuan Hukum Bagi Masyarakat Kurang Mampu di Indonesia. DIVERSI: Jurnal Hukum, 4(2), 218236. https://doi.org/10.32503/diversi.v4i2.374

Arifin, R. (2020). Legal Services and Advocacy in the Industrial Revolution 4.0: Challenges and Problems in Indonesia. Indonesian Journal of Advocacy and Legal Services, 1(2), 159-162. https://doi.org/10.15294/ijals.v1i2.36488

Arifin, R. (2020). Legal Protection and Law Enforcement: The Unfinished Works. Indonesian Journal of Advocacy and Legal Services, 2(1), 1-4. https://doi.org/10.15294/ijals.v2i1.38035

Arifin, R. (2020). Legal Reform Discourse in Indonesia and Global Context: How Does The Law Respond to Crime. Journal of Law and Legal Reform, 1(2), 193-196. https://doi.org/10.15294/jllr.v1i2.37057

Atikah, I. (2018). Implementasi E-Court dan Dampaknya Terhadap Advokat Dalam Proses Penyelesaian Perkara di Indonesia. URL: http://osc.fhisip.ut.ac.id/

Basri, B., \& Hendrawati, H. (2019). Pendidikan Hukum Indonesia Berorientasi Pada Nilai-Nilai Pancasila dalam Era Revolusi Industri 4.0. Pelita Bangsa Pelestari Pancasila, 14(1), 49-64. URL: https://pbpp.ejournal.unri.ac.id/index.php/JPB/article/view/7790

Diniyanto, A. (2020). Bureaucracy in Perspective of Government Administration Laws. Law Research Review Quarterly, 6(1), 85-90. https://doi.org/10.15294//rrq.v6i1.36706

Djatmiko, H. (2019). Implementasi Peradilan Elektronik (e-Court) Pasca Diundangkannya PERMA Nomor 3 Tahun 2018 Tentang Administrasi Perkara di Pengadilan secara Elektronik. Legalita, 1(1), 22-32. 
Hidayatno, A., Destyanto, A. R., \& Hulu, C. A. (2019). Industry 4.0 technology implementation impact to industrial sustainable energy in Indonesia: A model conceptualization. Energy Procedia, 156, 227-233 https://doi.org/10.1016/j.egypro.2018.11.133

https://ptun-yogyakarta.go.id/index.php/artikel/193-e-court-dan-masadepan-sistem-peradilan-modern-di-indonesia.html. February 22, 2020].

[Accessed

Iqbal, M., Susanto, S., \& Sutoro, M. Efektifitas Sistem Administrasi E-Court dalam Upaya Mendukung Proses Administrasi Cepat, Sederhana dan Biaya Ringan di Pengadilan. Jurnal Ilmu Hukum, 8(2), 302-315. http://dx.doi.org/10.30652/jih.v8i2.7286

Kurniati, I. A. (2019, March). Mengembalikan Citra Peradilan melalui ECourt. In Conference on Communication and News Media Studies (Vol. 1), 176-185. URL: http://proceeding.umn.ac.id/index.php/COMNEWS/article/view/1093

Manurung, E. H., \& Heliany, I. (2019). Peran Hukum dan Tantangan Penegak Hukum Dalam Menghadapi Era Revolusi Industri 4.0. SOL JUSTISIO, 1 (2 Oktober), 128-135.

http://ojs.mputantular.ac.id/index.php/sj/article/view/354

Meyrina, S. A. (2017). Perlindungan Hak Asasi Manusia bagi Masyarakat Miskin atas Penerapan Asas Peradilan Sederhana Cepat dan Biaya Ringan. Jurnal HAM, 8(1), http://dx.doi.org/10.30641/ham.2017.8.25-38

25-38.

Puhi, O., Akili, R. H., \& Moonti, R. M. (2020). The Settlement of Abuse of Authority by Government Officials. The Indonesian Journal of International Clinical Legal Education, 2(1), 85-100. https://doi.org/10.15294/ijicle.v2i1.37323

Rahmatullah, I. (2017). Menerobos Sekat Administrasi Peradilan. Refleksi Hukum: Jurnal Ilmu Hukum, 1(2), 117-130. https://doi.org/10.24246/jrh.2017.v1.i2.p117-130

Rodin, R. (2013). Transisi Masyarakat Indonesia Menuju Masyarakat Informasi. Jurnal Palimpsest, 4(2), 2013-05. URL: http://journal.unair.ac.id/download-fullpaperspalim9b3452ac9bfull.pdf

Saman, W. S. W. M., \& Haider, A. (2012). Electronic court records management: a case study (Doctoral dissertation, IBIMAInternational Busines Information Management Association), 1-11. DOI: $10.5171 / 2012.925115$

Santiadi, K. (2019). Expanding Access to Justice Through E-Court in Indonesia. Prophetic Law Review, 1(1), https://doi.org/10.20885/PLR.vol1.iss1.art5 
Sari, N. P. R. K. (2019). Eksistensi E-Court untuk Mewujudkan Asas Sedeerhana, Cepat, dan Biaya Ringan dalam Sistem Peradilan Perdata di Indonesia. Jurnal Yustitia, 13(1), 80-100. URL: http://www.ojs.unr.ac.id/index.php/yustitia/article/view/275

Septiar, R. R., \& Harahap, S. (2019). Implementasi Pengadilan Elektronik (E-Court) Pada Badan Peradilan di Indonesia dihubungkan dengan Asas Sederhana Cepat dan Biaya Ringan. Prosiding Ilmu Hukum, 5(2), 902-907. URL: http://hdl.handle.net/123456789/20728

Setyowati, H., \& Muchiningtias, N. (2018). Peran Advokat Dalam Memberikan Bantuan Hukum Kepada Masyarakat Dalam Perspektif Hak Asasi Manusia. Lex Scientia Law Review, 2(2), 155 - 168. https://doi.org/10.15294/lesrev.v2i2.27582

Singh, M., Sahu, G. P., Dwivedi, Y., Rana, N. P., \& Tamilmani, K. (2018). Success Factors for e-Court Implementation at Allahabad HighCourt. In PACIS (p. 137). URL: https://aisel.aisnet.org/pacis2018/137

Sudarsono, S. Konsep Peradilan secara Elektronik di Lingkungan Peradilan Tata Usaha Negara Pasca Diundangkannya Peraturan Mahkamah Agung Nomor 3 Tahun 2018. Tanjungpura Law Journal, 3(1), 42-65. http://dx.doi.org/10.26418/tlj.v3i1.34495

Waidner, M., \& Kasper, M. (2016, March). Security in industrie 4.0challenges and solutions for the fourth industrial revolution. In 2016 Design, Automation \& Test in Europe Conference \& Exhibition (DATE) (pp. 1303-1308). IEEE. URL: https://ieeexplore.ieee.org/abstract/document/7459511 


\title{
Quote
}

\section{There is a higher court than courts of justice and that is the court of conscience. It supercedes all other courts.}

\author{
Mahatma Gandhi
}

Copyrights (C) 2020 by Auhtor(s). This work is licensed under a Creative Commons Attribution-NonCommercial-ShareAlike 4.0 International License. All writings published in this journal are personal views of the authors and do not represent the views of this journal and the author's affiliated institutions. 
e-Court as an Effort to Modernize the Justice Administration

Indonesian Journal of Advocacy and Legal Services, Vol. 2 No. 1 (2020) 57 